\title{
Применение трековых мембран как сепараторов для разделения анодного и катодного пространств при индуцированном соосаждении Fe-W покрытий из цитратной ванны
}

\author{
В. В. Данильчук \\ Приднестровский госуниверситет им. Т.Г. Шевченко, г. Тирасполь, 3300, \\ e-mail:vik-dani@mail.ru \\ Поступила в редакцию 24.02.2020 \\ После доработки 02.05.2020 \\ Принята к публикации 03.05.2020
}

\begin{abstract}
Описаны возможности применения трековых мембран с различным размером пор (0,42-0,76 мкм) в качестве сепараторов для разделения анодного и катодного пространств при индуцированном соосаждении Fe-W покрытий из цитратной ванны. Показано, что их использование позволяет вдвое увеличить выход по току электроосаждения без увеличения энергоемкости процесса и обеспечить постоянство свойств покрытия (микротвердости) при длительном электролизе. Отмечается ограничение возможностей мембран, поскольку они выполняют роль только микрофильтров и не обладают ионообменными свойствами.
\end{abstract}

Ключевые слова: электроосаждение, индуцированное соосаждение, Fe-W, микротвердость, мембраны

УДК 541.138.2:544.654.2

https://doi.org/10.52577/eom.2021.57.2.7

Покрытия на основе металлов группы железа с вольфрамом в виде объемных материалов, тонких пленок или квазиодномерных структур интенсивно исследуются в последнее время в силу их уникальных механических, магнитных и антикоррозионных свойств [1-3].

Как показано в ряде работ [4-10], определяющую роль и в скорости осаждения, и в свойствах покрытий на основе металлов группы железа с вольфрамом, получаемых индуцированным соосаждением, играет материал анода. С целью уменьшения влияния анода в работах [4, 5, 7] использовано разделение анодного и катодного пространств и описано влияние разделения на состав, скорость осаждения и свойства (микротвердость) покрытий, в том числе применительно к получению $\mathrm{Fe}-\mathrm{W}$ покрытий.

В [4, 7] показана эффективность применения для этих целей трековых мембран в качестве сепараторов.

Трековые (ядерные) мембраны - вид фильтров, которые производят очистку с помощью мембранных процессов. Мембраны изготавливаются из полимерных пленок толщиной 12-23 мкм «бомбардировкой» высокоэнергетичными ионами криптона, пробивающими пленку насквозь. В местах прохождения ионов образуются каналы деструктированного материала (треки), отличающегося по своим физико-химическим свойствам от неповрежденного ионами материала [11].
Избирательное растворение деструктированного ионизацией материала превращает исходную пленку в микрофильтрационную мембрану со сквозными порами цилиндрической формы. При последующем травлении обработанной ионами пленки в растворе щелочи на месте треков образуются строго одинаковые сквозные отверстия - поры.

Диаметр этих пор в диапазоне от 0,05 до 5 мкм зависит от условий травления. Массовым производством трековых мембран занимается лаборатория ядерных реакций Объединенного института ядерных исследований (г. Дубна, Россия), производящая трековые мембраны с плотностью пор в диапазоне $10^{5}-3 \times 10^{9}$ пор/см². Пористость таких мембран составляет 10-15\%.

Основное свойство трековых мембран, отличающее их от других типов мембран, высокая селективность (одиночные поры имеют одинаковый диаметр с отклонениями не более 5\%). Поэтому в зависимости от функционального назначения (фильтрация механических примесей, бактериальных или вирусных суспензий и т.п.) может быть выбран соответствующий номинал трековой мембраны, оптимальный для определенного процесса микрофильтрации.

Для трековых мембран характерен ситовый механизм задержания микрочастиц. Поэтому трековые мембраны используются в качестве эталонного теста при определении селективности 
других типов фильтров. Трековые мембраны (ТM) характеризуются исключительно малой дисперсией пор по размерам (5-10\%), высокой селективностью и производительностью, имеют низкую адсорбционную способность по отношению к вирусам, клеткам, биополимерам, практически не содержат компонентов, способных мигрировать в фильтрат.

Действия на мембрану постоянного электрического поля способствуют направленному движению противоионов или электромиграции. Мембрана при полностью вымокшем состоянии является проводником. Удельное сопротивление изменяется в диапазонах двух порядков: от $1-2 \times 10^{-4}$ до $2 \times 10^{-2}(\mathrm{Oм} \cdot \mathrm{cm})^{-1}$ [11].

Таким образом, высокая электропроводность и идеальная селективность мембран являются основным транспортным свойством, обеспечивающим высокую производительность электромембранного процесса разделения. Необходимо подчеркнуть, что процесс фильтрации протекает на поверхности трековой мембраны и размеры пор не меняются в процессе фильтрации.

Другим видом используемых мембранных материалов являются ионообменные мембраны одни из наиболее известных и востребованных $[5,12]$. Ионообменные мембраны используются для конструирования топливных элементов, сенсоров и ряда других электрохимических устройств. Без таких мембран сейчас не обходится и электрохимическое производство (самый типичный пример - производство водорода и хлора). Именно для изготовления изолирующих перегородок, предотвращающих обратную диффузию продуктов в процессе получения хлора и щелочи при электролизе растворов хлорида натрия, фирмой “DuPont” в 1966 г. были разработаны и запатентованы широко известные перфторированные сульфокатионитные мембраны Нафион, которые до сих пор являются одними из лучших ионообменных мембран с точки зрения стабильности и транспортных свойств.

Одним из основных преимуществ перфторированных мембран является их термическая и химическая устойчивость за счет большей прочности C-F-связей [12]. Перфторированные катионообменные мембраны обычно состоят из различного количества фторуглеродных групп, на концах которых располагаются функциональные ионообменные группы. Удельное сопротивление ионообменных мембран $1,3 \times 10^{-2}(\mathrm{OM} \cdot \mathrm{cm})^{-1}$.

Настоящая работа, являющаяся продолжением работ [4, 7], посвящена более детальному исследованию свойств трековых мембран как сепараторов применительно к электроосаждению $\mathrm{Fe}-\mathrm{W}$ покрытий.

\section{МЕТОДИКА ЭКСПЕРИМЕНТА}

Электролит включал как соль сульфата двухвалентного железа, так и вольфрамат натрия. Цитратная ванна, использованная в этом исследовании, содержала $\mathrm{FeSO}_{4}(0,17 \mathrm{M})$, $\mathrm{Na}_{2} \mathrm{WO}_{4}(0,34 \mathrm{M})$, лимонную кислоту $(0,17 \mathrm{M})$ и тринатрийцитрат $(0,33 \mathrm{M})$. Готовился он предварительным растворением сульфата железа в цитратном буферном растворе с последующим растворением в этом растворе вольфрамата натрия, $\mathrm{pH}$ полученного раствора был равен 6,8-6,9. Концентрация трехвалентного железа составляла $~ 80-90 \%$ от общей концентрации железа.

В качестве разделительной мембраны использовали микрофильтрационные мембраны (MF) со средним диаметром пор 0,74 и 0,42 мкм (производства г. Дубна, Россия). Специальные измерения показали, что наличие мембраны подобного типа не приводило к увеличению напряжения при электролизе в гальваностатических условиях, а следовательно, к повышению энергоемкости процесса.

Эксперименты проводились с использованием как графитового анода (графит ТМ-3) в ячейке с разделенными катодным и анодным пространствами емкостью 0,5 л в отсутствие перемешивания, так и растворимого железного $[4,13]$.

Площадь поверхности катода составляла $1 \mathrm{~cm}^{2}$. Осаждение осуществляли при постоянной плотности катодного тока, равной $2 \mathrm{~A} /$ дм $^{2}$, и температуре $80^{\circ} \mathrm{C}$.

Концентрацию железа в процессе электролиза определяли спектрофотометрически в присутствии сульфосалициловой кислоты. Вначале определяли общее содержание железа в пробе. К аликвотной части пробы, приготовленной в бескислородных условиях (аргон, кипяченая вода), прибавляли раствор сульфосалициловой кислоты и разбавленный раствор аммиака (2:3) и выдерживали в течение 10 мин. Определяли оптическую плотность раствора при 430 нм. Общую концентрацию железа вычисляли по предварительно построенному калибровочному графику. Далее определяли содержание железа (III) в пробе. Для этого к аликвотной части пробы прибавляли необходимое количество сульфосалициловой кислоты и доводили $\mathrm{pH}$ до 1 прибавлением раствора соляной кислоты (3:2), выдерживая в течение 10 мин. Определяли оптическую плотность раствора при 510 нм. Концентрацию железа (III) определяли по калибровочному графику. Содержание железа (II) в пробе находили по разнице между общим количеством железа и содержанием железа (III) в пробе. Спектрофото- 

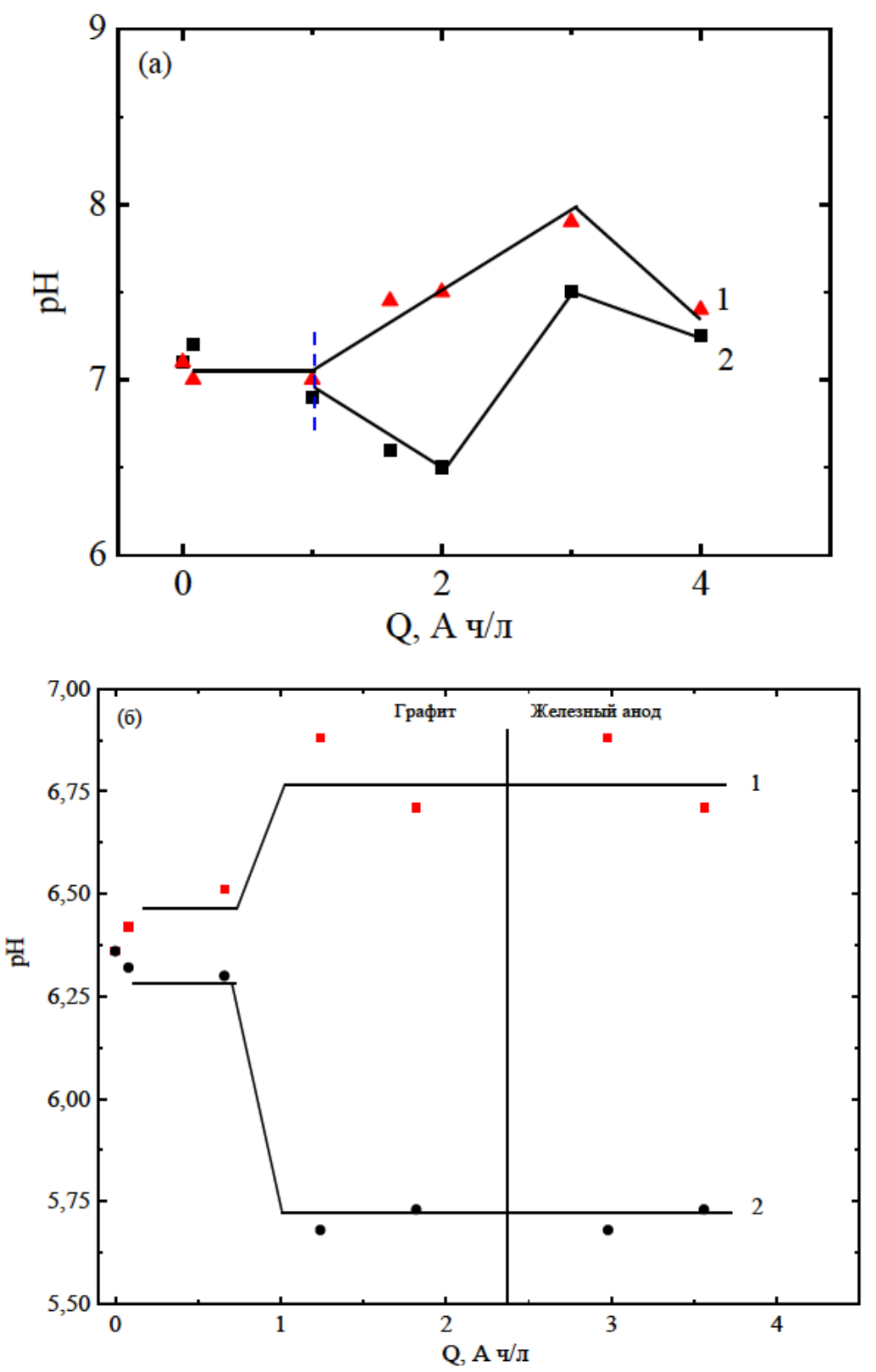

Рис. 1. Изменение $\mathrm{pH}$ католита (1) и анолита (2) в процессе электроосаждения сплава Fe-W: мембрана со средним диаметром пор 0,76 мкм (а); мембрана со средним диаметром пор 0,42 мкм (б).

метрические измерения проводились на модифицированном (сопряженным с компьютером) спектрофотометре SpecordM40 в кварцевых кюветах размером от 1 до $10 \mathrm{Mм}$.

Определение $\mathrm{WO}_{4}{ }^{2-}$ в растворе выполняли фотоколориметрическим роданидным методом после его восстановления Sn (II) и Тi (III) до $\mathrm{W}(\mathrm{V})$ в солянокислой среде (3-4 M) с образованием соответствующего окрашенного комплекса желто-зеленого цвета и последующим измерением оптической плотности раствора при длине волны 400 нм. Вольфрам определяли на фоне сопутствующих элементов. Устранение мешающего влияния ионов $\mathrm{Fe}^{3+}$ и $\mathrm{Fe}^{2+}$ осуществляли путем их связывания избытком сегнетовой соли. Выход по току (ВТ) сплава определялся при использовании в качестве электрохимического эквивалента 1,09 г/А.ч [10]. При используемой плотности тока электро-осаждения и графитовом аноде выход по току ВТ из этого электролита с неразделенным анодным и катодным пространствами составил $32 \%[4,13]$. При использовании растворимого железного анода наблюдался заметный рост ВТ $[4,13]$.

Морфологию полученных поверхностей и анода определяли с использованием электронного микроскопа (SEM) HitachiTM 360, a их химический состав $\mathrm{c}$ помощью EDS-приставки к этому микроскопу, а также с применением XRF анализа (X-Calibur, Xenemetrix, Израиль).

Микротвердость покрытий исследовали микротвердомером ПМТ-3 при нагрузке 100 г с применением индентора Виккерса. Для одной площади поверхности использовали не менее трех измерений. 


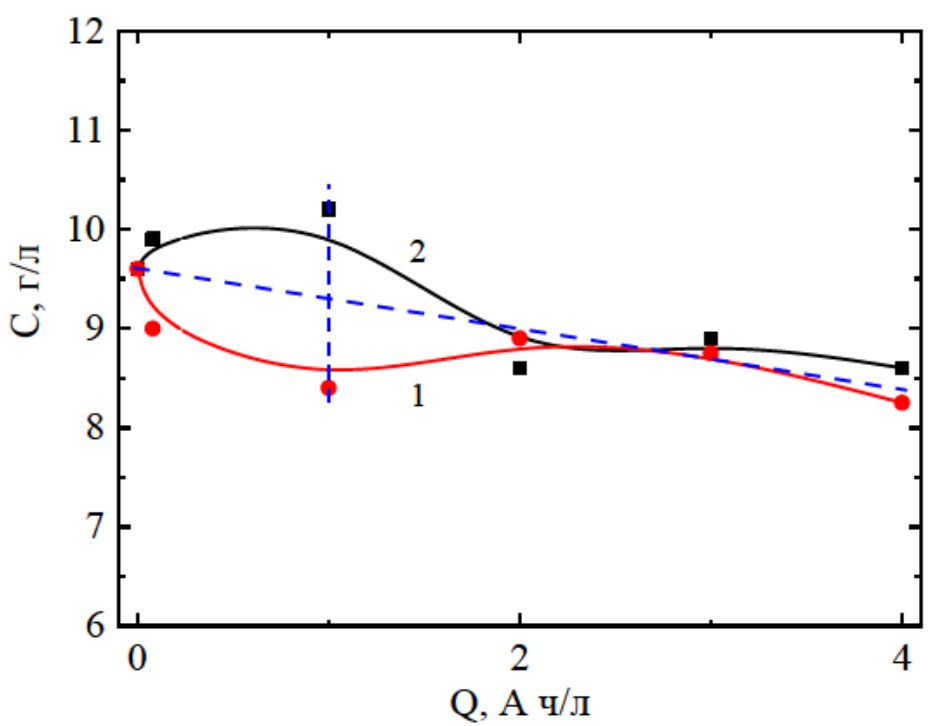

Рис. 2. Изменение концентраций железа в католите $(I)$ и анолите (2) в процессе катодного получения сплава $\mathrm{Fe}-\mathrm{W}$ при использовании разделенных анодного и катодного пространств. Мембрана со средним диаметром пор 0,76 мкм [4].

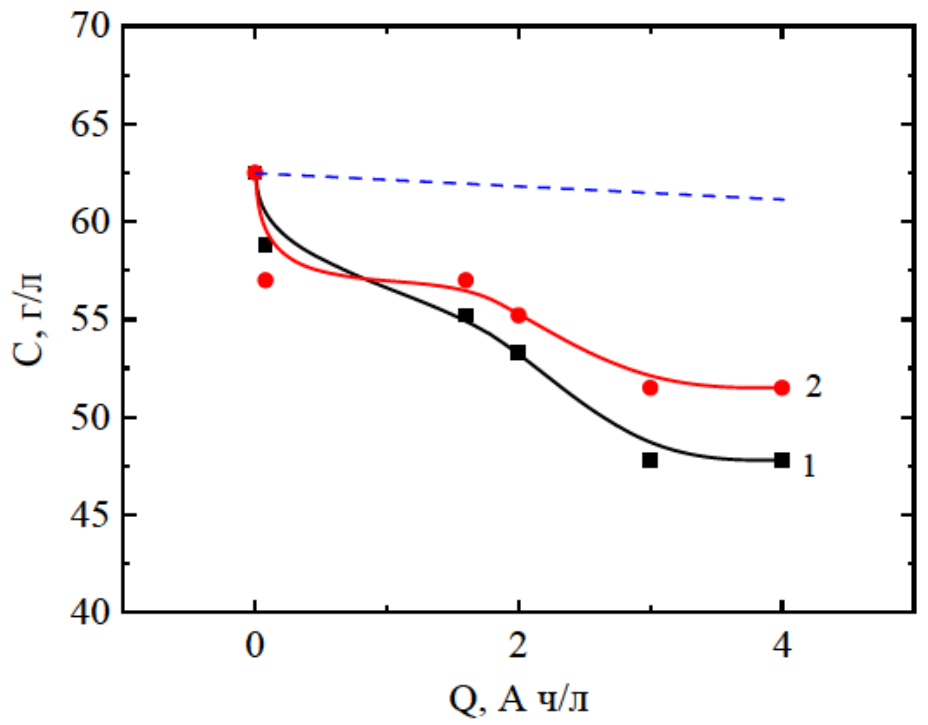

Рис. 3. Изменение концентраций вольфрама в католите (l) и анолите (2) в процессе катодного получения сплава $\mathrm{Fe}-\mathrm{W}$ при использовании мембраны с диаметром пор 0,76 мкм. Пунктиром показаны расчетные изменения концентраций компонентов (пояснения в тексте) [4].

\section{РЕЗУЛЬТАТЫ И ИХ ОБСУЖДЕНИЕ}

В процессе электроосаждения необходимо поддерживать $\mathrm{pH}$ электролита. Результаты, приведенные на рис. 1, демонстрируют, что $\mathrm{pH}$ исходного электролита в процессе электролиза, по крайней мере до значений $Q \sim 1$ А.час/л, сохраняется как в катодном, так и анодном пространствах для мембран с различным размером пор. Однако, после 1 А.час/л $\mathrm{pH}$ католита начинает повышаться, а анолита, наоборот, понижаться. При этом до значений $Q \sim 1$ А.час/л общая концентрация железа в анолите повышается, несмотря на снижение общей концентрации железа ввиду его перехода в сплав (показано пунктиром на рис. 2). Концентрация железа в католите при этом оказывается существенно ниже, чем рассчитанная в предположении еe снижения только вследствие электроосаждения (рис. 2).
Как видно из рис. 1, меньший размер пор мембраны позволяет стабилизировать значения $\mathrm{pH}$ в широкой области времени электролиза независимо от природы анодных процессов, окисления компонентов электролита или анодного растворения при использовании растворимого железного анода.

Изменения концентраций железа в катодном и анодном пространствах является следствием миграции цитратных комплексов двухвалентного железа в анодное пространство, его окисления и полимеризации. Измерения концентрации двухвалентного железа в анолите показали, что после 1 А.час/л концентрация становится равной нулю (в отличие от концентрации двухвалентного железа в католите при том же количестве пропущенного заряда).

Отсутствие восстановленной формы железа в анолите приводит к тому, что процесс окисления комплекса двухвалентного железа замещается на 


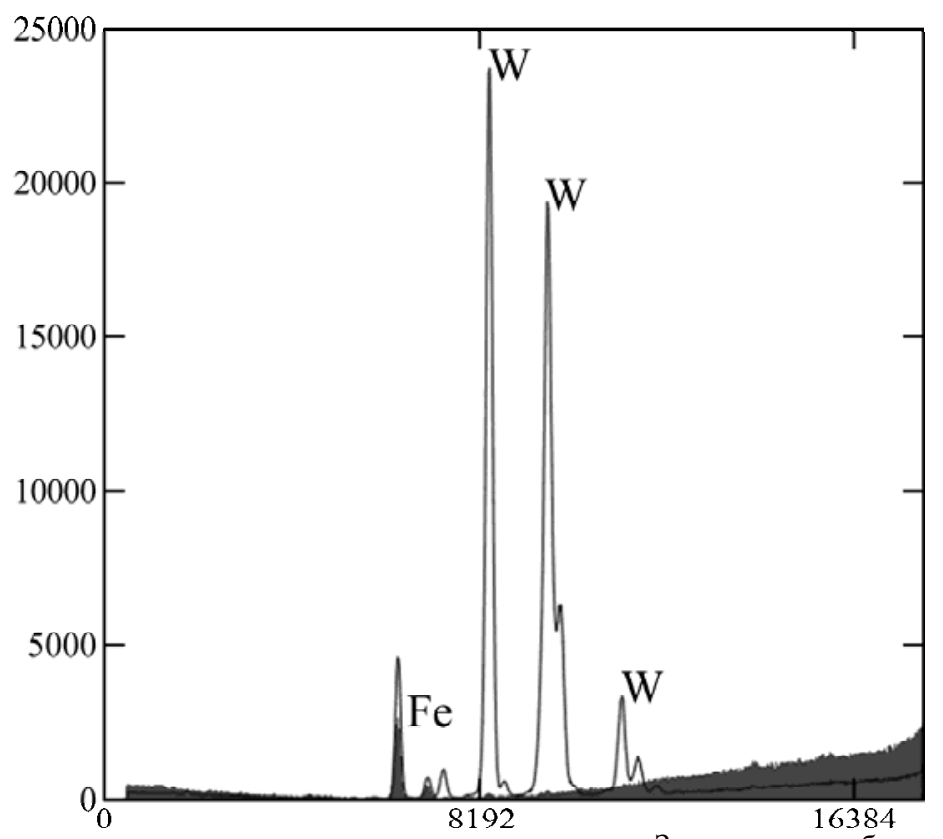

Рис. 4. XRF-спектр графитового анода после длительного электролиза. Закрашенная область - спектр после электроосаждения из цитратного электролита, не содержащего вольфрамат, не закрашенная - спектр после длительного электролиза получения $\mathrm{Fe}-\mathrm{W}$ сплавов.

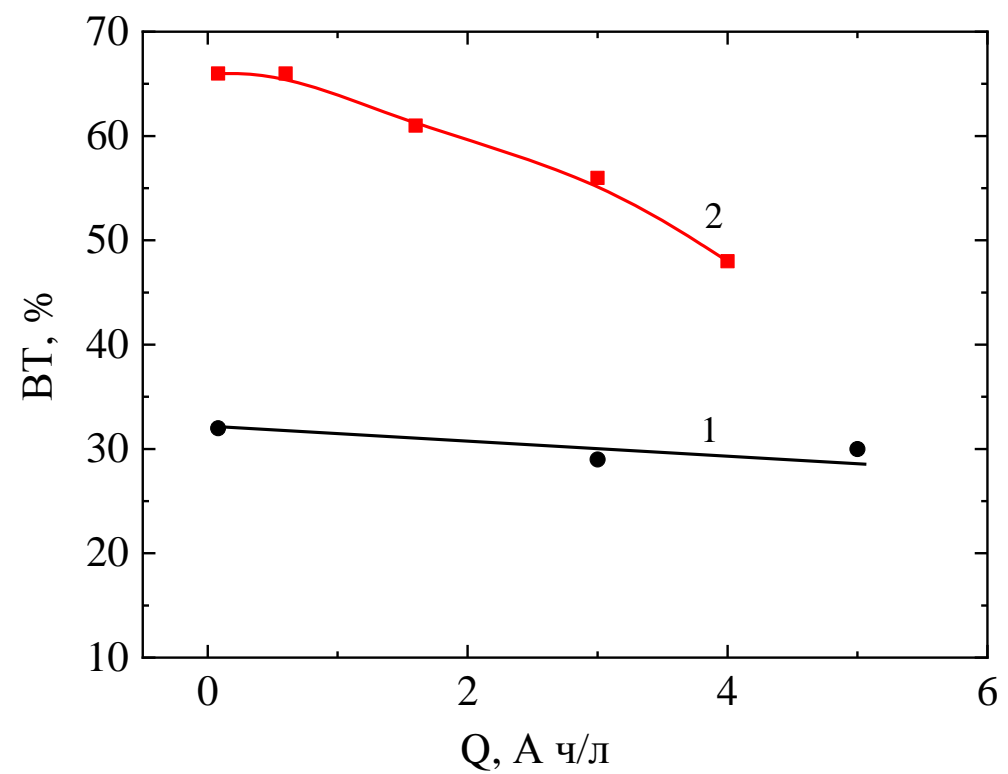

Рис. 5. Влияние степени эксплуатации электролита $Q$ на зависимость выхода по току катодного осаждения сплава при неразделенных (1) и разделенных (2) анодном и катодном пространствах. Мембрана со средним диаметром пор 0,76 мкм [4].

реакцию окисления растворителя (воды) с увеличить выход по току катодного электровыделением кислорода, следствием чего является осаждения ([4] и будет показано ниже). Свойства подкисление анодного пространства (рис. 1). мембраны (фильтр со средним диаметром пор Подкисление приводит к коагуляции образовав- 0,74 мкм) не позволяют поддерживать эффекшейся коллоидной системы, в результате чего тивное разделение в течение длительного происходят выравнивание концентраций железа электролиза, поскольку уже при степени эксплув анодном и катодном пространствах и совпа- атации электролита $\sim 4$ А·час/л ВТ снижается до дение измеренных концентраций с рассчи- 50\% [4]. Тем не менее, даже при длительном танными, исходя из их уменьшения вследствие электролизе ВТ при описанном выше методе электроосаждения на катоде (рис. 2). разделения электродных пространств сущеУменьшение диаметра пор мембраны приводит к ственно превышает наблюдаемый с нераздезадержанию продуктов реакции, получаемый эффект виден при падении концентрации железа на рис. 2.

Разделение анодного и катодного пространств, позволяет существенно (в 2 раза) ленными пространствами. Несмотря на то что при относительно коротком времени электролиза имеет место расхождение в концентрациях в анолите и католите, при длительном времени концентрации выравниваются и имеет место 


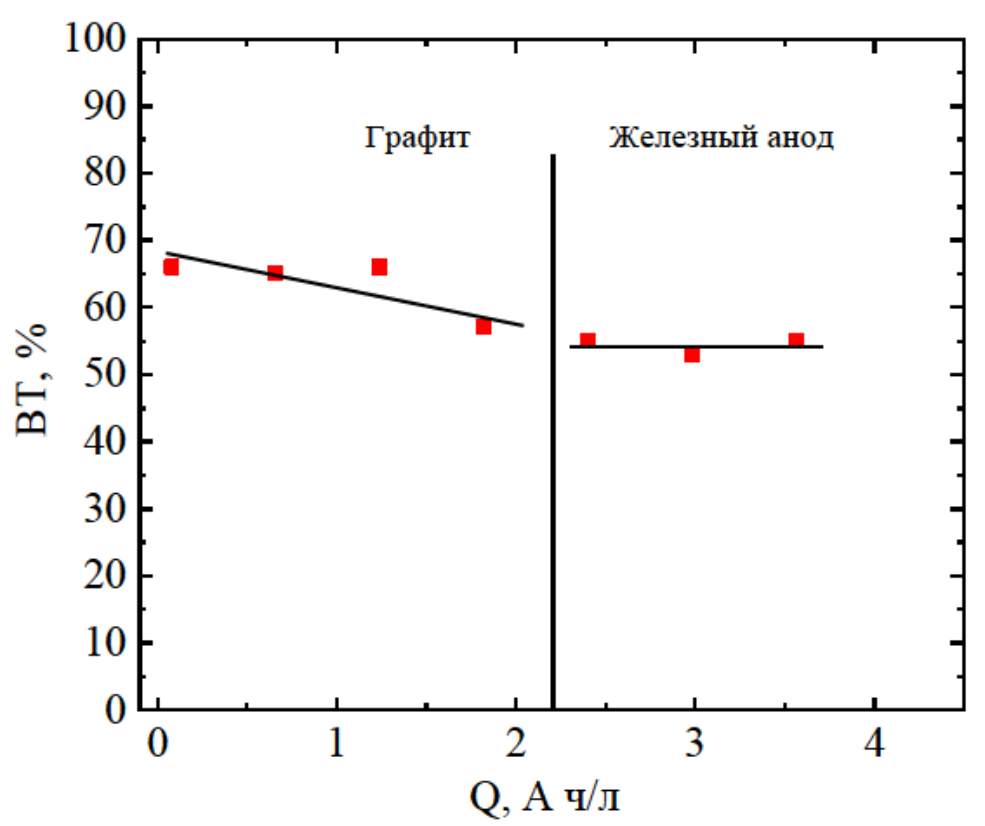

Рис. 6. Влияние степени эксплуатации электролита $Q$ на зависимость выхода по току катодного осаждения сплава при разделенных анодном и катодном пространствах. Мембрана со средним диаметром пор 0,42 мкм.

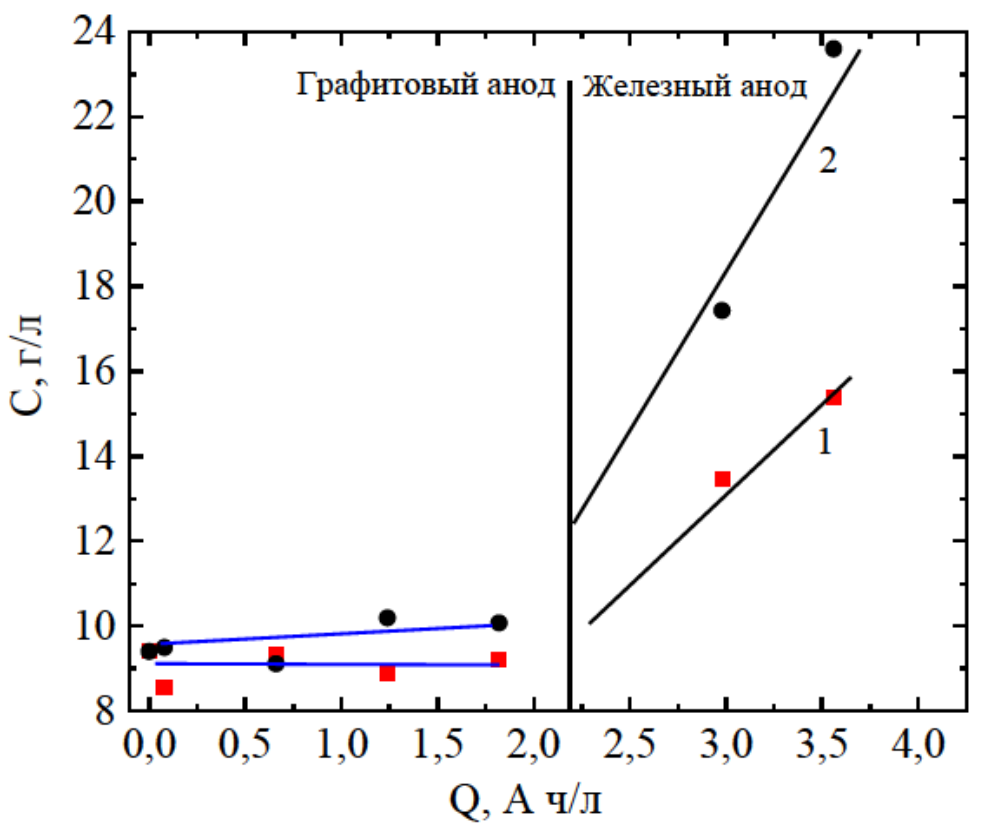

Рис. 7. Изменение концентраций железа в католите (I) и анолите (2) в процессе катодного получения сплава $\mathrm{Fe}-\mathrm{W}$ при использовании разделенных анодного и катодного пространств. Мембрана со средним диаметром пор 0,42 мкм.

падение ее в соответствии с осаждением на аноде.

Концентрация вольфрамата в электролите постоянно снижается, степень ее снижения существенно выше рассчитанной вследствие электроосаждения вольфрама в сплав (рис. 3).

Причиной снижения концентрации вольфрама является абсорбция его в графитовый анод (рис. 4). XRF - спектр графитового анода показывает абсорбцию графитовым анодом не только вольфрама, но и железа. Таким образом, если уменьшение концентрации комплекса металлосадитель (цитратного комплекса железа) имеет место в основном вследствие электроосаждения, то изменение концентрации вольфрамат-иона при электролизе происходит как вследствие электроосаждения, так и поглощения его графитовым анодом. Очевидно, что поглощение соли вольфрама анодом является одной из причин наблюдаемого ранее повышения эффективности электроосаждения $\mathrm{Co}-\mathrm{W}$ покрытий при использовании растворимого вольфрамового анода вместо нерастворимого графитового [8].

Существенное падение концентрации солей $\mathrm{Fe}$ и W в электролите приводит к падению ВТ в процессе электролиза (рис. 5).

Несмотря на рост значения ВТ при использовании трековых мембран по сравнению с неразделенными пространствами этого недостаточно, поскольку ВТ все-таки снижается. Уменьшение размеров пор мембраны с целью уменьшения количества миграции продуктов 


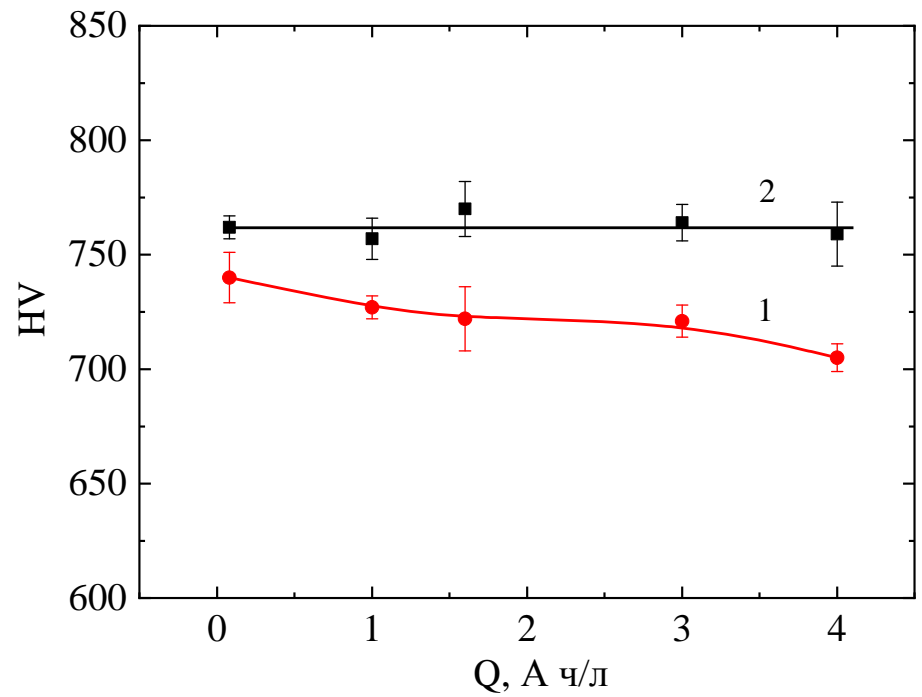

Рис. 8. Микротвердость Fe-W покрытий, полученных с разделенными анодным и катодным пространствами, при различных степенях эксплуатации электролита до удаления поверхностного слоя (1) и после (2) [4].

распада (рис. 1) принципиально проблему не решает. При использовании графитового анода и мембраны с меньшим размером пор ВТ снижается при длительном электролизе (рис. 6).

Очевидной причиной снижения ВТ является наличие побочного процесса восстановления $\mathrm{Fe}(\mathrm{III})$ до $\mathrm{Fe}(\mathrm{II})$ вследствие увеличения концентрации $\mathrm{Fe}(\mathrm{III})$ в анодном процессе на графитовом электроде и переноса его в катодное пространство. Решить возникшую проблему возможно введением растворимого железного анода. В этом случае реакция окисления с образованием $\mathrm{Fe}(\mathrm{III})$ заменяется реакцией анодного растворения с образованием $\mathrm{Fe}(\mathrm{II})$.

Таким образом, можно сделать вывод о недостаточности разделения анодного и катодного пространств, поскольку, хотя концентрация железа в католите и снижается примерно на 50\% по сравнению с анолитом, это не решает проблему из-за существенного роста концентрации железа (рис. 7). Это позволяет поддерживать постоянство ВТ (рис. 6) ценой существенного роста концентрации железа в католите (рис. 7).

Следствием разделения электродных пространств с использованием трековых мембран является тот факт, что и состав, и морфология покрытий практически не изменяются при длительном электролизе. Снижение микротвердости (рис. 8) может быть следствием наличия кислородсодержащих примесей в покрытии [4, 7-9, 14]. Их удаление с поверхности простым механическим шлифованием (происходило удаление поверхностного слоя порядка 3 мкм, поскольку именно такова толщина оксидного слоя при электроосаждении Fe-W покрытий) приводило: a) к повышению микротвердости; б) постоянству ее значений независимо от времени электролиза (рис. 8).
Несмотря на очевидную недостаточность разделения, основное свойство (микротвердость) сохраняется постоянным (рис. 8) при длительном электролизе. Дальнейшие возможности совершенствования процесса электроосаждения с применением трековых мембран состоят в использовании сложных анодов $[5,6,10]$.

\section{ВЫВОДЫ}

В заключение необходимо подчеркнуть, что использование трековых мембран как разделителей электродных пространств применительно к индуцированному соосаждению Fe-W (а также, возможно, покрытий металлов группы железа с вольфрамом):

- обеспечивает снижение негативного влияния анодных процессов на скорость осаждения и свойства получаемых покрытий;

- позволяет поддерживать $\mathrm{pH}$ в условиях длительного электролиза;

- в сочетании с использованием растворимых анодов позволяет поддерживать скорость осаждения и свойства покрытий постоянными при длительном электролизе;

- обладает ограниченными возможностями в качестве сепаратора, поскольку трековые мембраны являются только микрофильтрами и не обладают свойствами ионообменных мембран.

\section{ФИНАНСИРОВАНИЕ РАБОТЫ}

Работа выполнена в рамках бюджетного финансирования Приднестровского Госуниверситета им. Т.Г. Шевченко (г. Тирасполь).

\section{ЛИТЕРАТУРА}

1. Eliaz N., Gilead N., Induced Codeposition of Alloys of Tungsten, Molybdenum and Rhenium with Transition Metals. Mod. Aspect. Electroch., 2008, vol. 42, p. 191. https://doi.org/10.1007/978-0-387-49489-0_4 
2. Tsyntsaru N., Cesiulis H., Donten M., Sort J. et al. Modern trends in tungsten alloys electrodeposition with iron group metals, Surf. Eng. Appl. Electrochem., 2012, vol. 48, no. 6, p. 491. https://doi.org/10.3103/s1068375512060038

3. Cesiulis H., Tsyntsaru N., Podlaha E., Deyang Li. et al. Electrodeposition of Iron-Group Alloys into Nanostructured Oxide Membranes: Synthetic Challenges and Properties, Curr. Nanosci., 2018, vol. 14, p. 1. https://doi.org/10.2174/ 1573413714666180410154104

4. Белевский С.С., Данильчук В.В., Готеляк А.В., Лелис М. и др. Электроосаждение $\mathrm{Fe}-\mathrm{W}$ сплавов из цитратного электролита. Роль материала анода, ЭОМ, 2020. т. 56, № 1, с. 14. doi: 10.5281/zenodo.3639943

5. Ishida K., Morikawa T., Miyake M., Hirato T. Influence of $\mathrm{Fe}(\mathrm{III})$ in Fe-W Alloy Plating and Continuous Plating Using Ion Exchange MembraneMultiple Anode System, J. Surf. Finish. Soc. Japan, 2016, vol. 67, no. 9, p. 489 https://doi.org/10.4139/sfj.67.489

6. Кабанда А., Кукушкина К.В., Соболь О.Е., Ярлыков М.М. и др. Электрохимическое поведение растворимых анодов в цитратноаммиачных электролитах электроосаждения сплава никель-вольфрам, Гальванотехника $u$ обработка поверхности, 1998, т. VI, № 3, с. 24.

7. Danil'chuk V.V., Shulman A.I., Gotelyak A.V., Yushchenko S.P. et al. Electrodeposition of Fe-W Coatings from a Citric Bath with Use of Divided Electrolytic Cell, Russ. J. Appl. Chem., 2020, vol. 93, no. 3, p. 372. https://doi.org/10.1134/S107042722003009X

8. Belevski S.S., Bobanova Zh.I., Buravets V.A., Gotelyak A. V. et al. Electrodeposition of Co-W Coatings from Boron Gluconate Electrolyte with A Soluble Tungsten Anode, Russ. J. Appl. Chem., 2016, vol. 89, no. 9, p. 1427. https://doi.org/10.1134/s107042721609007x
9. Белевский С.С., Готеляк А.В., Силкин С.А., Дикусар А.И. Макроскопический размерный эффект микротвердости покрытий из сплавов металловгруппы железа с вольфрамом: роль электродного потенциала и кислородсодержащих примесей, ЭОМ, 2018, т. 54, № 2, с. 9.

10. Дикусар А.И., Силкин С.А., Данильчук В.В., Яковец И.В. и др. Способ получения нанокристаллических кобальт-вольфрамовых (Со-W) покрытий с использованием растворимых анодов. Патент № 483 F1 от 28.11.2017, 7 с.

11. Головков В.М. и др. Особенности получения трековых мембран с помощью циклотрона типа У-120, Известия вузов. Физика, 1998, № 4, с. 187.

12. Ярославцев А.Б. Перфторированные ионообменные мембраны, Высокомолекулярные соединения. Серия $A$, 2013, т. 55, № 11, с. 1367. doi: 10.7868/S0507547513110068

13. Белевский С.С., Готеляк А.В., Ющенко С.П., Дикусар А.И. Электроосаждение нанокристаллических $\mathrm{Fe}-\mathrm{W}$ покрытий из цитратного электролита, ЭОМ, 2018, т. 54, № 5, с. 31.

14. Gotelyak A.V., Silkin S.A., Yahova E.A., Dikusar A.I. Effect of $\mathrm{pH}$ and Volume Current Density on Deposition Rate and Microhardness of Co-W Coatings Electrodeposited from Concentrated Borongluconate Electrolyte, Russ. J. Appl. Chem., 2017, vol. 90, no. 4, p. 541. https://doi.org/10.1134/s1070427217040085

\section{Summary}

The possibilities of the track membranes with the pore different sizes $(0.42-0.76 \mu \mathrm{m})$ for the separation of cathode and anodic spaces at induced codeposition of Fe-W coatings from a citrate bath are described. The use of track membranes allowed to increase for about twofold the current efficiency of electrodeposition without increasing the energy intensity and to ensure the constancy of microhardness during continuous electrolysis. It is noted that membranes have limited capabilitiessince they only play the role of microfilters and do not have ion-exchange properties.

Keywords: electrodeposition, induced coprecipitation, Fe-W coatings, microhardness, membranes 